\title{
Relationship of representations about the object of activity and time perspectives for teachers of different ages
}

\author{
Lyudmila Zheldochenko ${ }^{1,{ }^{*}}$ and Oksana Nikolenko ${ }^{2}$ \\ ${ }^{1}$ Southern Federal University, Russia, Rostov-on-don \\ ${ }^{2}$ Don State Technical University, Russia, Rostov-on-don
}

\begin{abstract}
The article analyzes the problem of professionalization of the individual in pedagogical activity. The results of an empirical study of the ideas of teachers of different ages about the object of their professional activity are presented. It is shown that at each stage of professionalization, with an increase in the length of teaching experience, the assessment of the attitude to time changes, and through this - the assessment of the individual's attitude to the surrounding reality in General, as well as to himself, his experience and future prospects. Significant relationships between indicators of teachers ' perceptions of the object of professional activity and indicators of the time perspective of teachers of different ages are shown. The study involved 148 College teachers. Work experience varies from 1 year to 40 years. Age limits from 20 to 63 years. To confirm the research hypothesis that there may be significant relationships between professional ideas and time perspectives among teachers of different ages, we used a set of methods, including:"Questionnaire aimed at the study of ideas about the object of activity (E. I. Rogova)," F. Zimbardo's time perspective Questionnaire (ZTPI)". Methods of mathematical and statistical processing, presentation of the obtained data: descriptive statistics, determination of the reliability of differences: according to the Kruskal-Wallace criterion. Empirically, it is established that there are significant relationships between the assessment of attitudes to time and ideas about the object of activity in teachers of different ages.
\end{abstract}

\section{Introduction}

The problem of professional development of a teacher, today, is more relevant than ever. Today, the labor market is in demand for highly professional teachers who possess innovative methods and technologies, are ready for constant professional growth, self-development and self-actualization, have, along with this, formed skills of psycho-emotional self-regulation, and are ready for intensive interaction with the subjects of the educational space. There are new types of activities, and in accordance with this, new professions. Time changes its course, begins to run faster and faster, and modern people need to catch this and live, focusing their life activities on the General flow. Long-term research by D. G. Elkin shows that there

\footnotetext{
* Corresponding author: ludmilakateryna@yandex.ru
} 
is a direct connection between the perception of time and activity: the more accurate the perception of time, the more successful the activity [1]. Professional self-determination is a subject of constant research interest for scientists and practitioners. Such concepts as selfrealization and self-actualization are close to self-determination in Russian and foreign psychology. One of the founders of humanistic psychology, A. G. Maslow, proposed the concept of professional development and identified self-actualization as a Central concept as a person's desire to improve, Express, and manifest himself in a meaningful business. In the concept, close to the concept of "self-determination" are such concepts as" selfactualization"," self-realization "and" self-fulfillment " [2]. According to A.V. Mudrik, selfdetermination is the Central mechanism of personal maturity, which consists in a person's conscious choice of their place in the system of social relations. E. F. Zeer defines "professional self-determination" as an active and long-term process of choosing a profession, internal psychological grounds and the result of this process. The content of professional self-determination - "awareness of the world of professions, ways of choosing them, ways of mastering professions; self-analysis and self-assessment". Zeer considers professional self-determination based on a person's awareness of their capabilities in a particular area, readiness for self-determination [3]. E. Y. Pryazhnikova notes that "professional self-determination"of an individual as a process has different tasks depending on the stage of professional development and the person's belonging to a certain professional group. "The essence of professional self-determination is self-conscious and finding meanings choose or already performed work and all of life in a particular socio-economic situation, as well as finding meaning in the very process of self-determination" [4] S. N. Chistyakova considers professional identity as a commitment to the profession and defines it as a steady integral system of professionally important qualities of personality(positive attitude to elect the type of professional activity, the necessary knowledge, abilities, skills) [5]. A person, as a subject of professional self-determination, assumes responsibility for making a choice and its consequences. A person builds and corrects their professional intentions and plans, makes professional choices and carries out their professional development. But this process is influenced by objective and subjective factors, the most important of which are the subjective characteristics of the individual, as well as the specifics of professional activity. Professional self-determination " begins with the choice of a profession, but does not end there, since a person faces a continuous series of professional choices throughout his life. Professional representations are an important component of professional self-determination. At the same time, the development of professional ideas depends on the student's personal self-determination, the development of his life plans, individual characteristics, cognitive activity, values, ideals, and interests $[6,7]$.

Professional ideas are related not only to the student's professional and personal selfdetermination, but also to their life and professional position. Professional ideas begin to take shape when choosing a profession. Professional ideas arise at the initial stages of professional self-determination and change in the process of professional training [8,9]. The idea of the " I " image "as a subject" is one of the criteria for "professional self-determination". The subjective image of a professional's Self is influenced by the standard of a professional. Usually, in the first year, the image of "I as a subject of future professional activity" is replaced by fragmentary knowledge about the subject, object of work and its operational side. The process of professional self-determination of an individual can be considered as a process that unfolds in two planes: determining one's place in the world of professions and determining the place of the profession in one's life. Both in the first and second process, a person can and should show their own activity, and in the first and second cases, this (subjective) activity should become decisive in solving the problems of choosing a profession and preparing for it [10].. The most important criterion for understanding and productivity of professional development of an individual is their ability to find personal meaning in 
professional work, independently design, create their professional life, and responsibly make decisions about choosing a profession, specialty, and place of work. Considering the process of becoming a specialist, we can distinguish different stages of professionalization, in particular: the formation of professional intentions; professional training; professionalization $[11,12,13]$.

Scientists research on the perception of time and time perspective factors and the impact of these phenomena on the process of professionalization is of interest. Time perception is a unique type of perception that reflects the duration of an event. Time relations are expressed by means of: chronometry-counting time measured by the uniform movement of an object, such as the hand of a clock; chronology-reflecting time in accordance with common phenomena for all people: the seasons, the number of years lived, etc.; Chronographe subjective time, i.e. the subjective experience of the duration of the events depending on their importance and emotional coloring [14].

There are differences in the perception of time: the immediate sense of duration, which is its sensory basis, is mainly due to visceral sensitivity, the actual perception of time, which develops on this sensory organic basis. Just as in relation to space one distinguishes between elementary extension and space proper, so in relation to time one must distinguish between two concepts - duration and time proper, but in order to combine them into a single whole. There are differences in the actual perception of time: the perception of the duration of time; perception of the time sequence. They are included in unity and interpenetration through direct and indirect components. There is some direct experience, sensation, or "sense" of time in the human body. It is caused by organic sensations and is associated with the rhythm of the main processes of organic life-pulse, respiration, etc. A significant role in the "sense" or sense of time is played, apparently, by irreversible chemical reactions in the nervous system. Individual differences also affect the subjective assessment of time. In experiments. Some subjects demonstrated a very strong tendency to underestimate the time, while others have overestimated the time. Ehrenwald therefore considers it possible to distinguish between two types of time perception - the bradychan and the tironian. The first shows a more or less stable tendency to accelerate; the second-to slow down, to delay. The first overestimates, the second underestimates the duration of time intervals [15]. Interaction with time is a fundamental characteristic of human experience, both objective and subjective. The psychological time of the individual is a link between all the structures of reality, permeates all spheres of human life, both external and internal. Future-oriented questionnaires study the extent to which a person is preoccupied with likely future events, sometimes contrasting future orientation with past/present orientation [16].

\section{Problem statement}

In scientific literature the problem of professional performances is investigated from different angles: the relationship of professional performances with educational motivation, the dynamics of the development of ideas about the profession at different stages of learning are studied in the works of L. D. Galdacano, S. V. Zholudeva, M. V. Naumenko, I. A. Pankratova, E. I. Rogov and others. Studies of professions and professional education are reflected in the research of I. V. Vachkov, Yu. M. Zabrodin, E. F. Zeer, M. M. Kashapov, Yu. P. Povarenkov, A. K. Markova, and others. Psychological and acmeological features of representations as regulators of personal and professional development and relationship formation were studied by E. N. Bogdanov, A. A. Derkach, V. A. Zobkov, I. P. Krasnoshchechenko, N. V. Kuzmina, E. V. Selezneva, and others. Comparative studies of generations represented in the scientific works of A.V. Tolstykh, M. I. Postnikova, M. V. Zaporowski. Theoretical propositions about mentality as a differentiating criterion of generations are presented in the works Of V. I. Pischik and others. The theory of G.Allport, 
N. Howe and W. Strauss is devoted to the cyclicity of generations. Ideas about the future profession are the basis of the process of professionalization of the individual and are associated not only with professional and personal self-determination, but also with its life and professional position. Professional ideas begin to take shape when choosing a profession. Professional ideas arise at the initial stages of professional self-determination and change in the process of professional training. The problem of representations is an interdisciplinary one, it has been considered in philosophy, physiology, cognitive and social psychology, as well as abroad: F. Galton, V. Wundt, M. Wertheimer, E. Durkheim, L. Levi-Bruhl, A. Meinong, J. piaget, C. S. Sherrington, K. Jung, and in Russia:B. G. Ananyev, H. A. Bernstein, B. F. Lomov, D. A. Oshanin, I. M. Sechenov, S. D. Smirnov, B. M. Tegsho V and others. Most authors consider representations as "generalized images of reality", " images-goals that guide cognitive, educational activities and any other, including professional activities. Professional ideas were studied in the works of A. I. Dontsov, II. V. Komusova, and T. V. Kudryavtsev. E. F. wrote about professional ideas as a condition for choosing a profession. Zeer, E. A. Klimov, etal.Professional representations are always historically determined and reflect a person's personal life experience and worldview. Analysis of the works of V. D. Bragina, P. L. Kirt, V. N. Obnosov, PL. Sergeeva allowed us to reveal the professional concept. In professionalnom view, G. S. Pomaz identifies three structural components, which include: "submission of professii and personality of the professional (a social example, the standard of a professional, the image of a profession that reflectsthe subject and is supplemented by his own impressions of the profession); the idea of himself as a future professional ("Self-image", "identified" with this specialty and transformed on its basis); the idea of a possible professional future (the image of a probable future associated with the predicted social status and the possibility of personal and professional growth).

\section{Purpose of research}

The purpose of this study was to study the professional development of a person in teaching, as well as to identify significant relationships between the ideas of the IOB object of activity and the time perspective of teachers of different ages.

\section{Method of research}

In our study, to confirm the hypothesis that. that it is possible that there are significant relationships between professional ideas and time perspectives for teachers of different ages, we used a set of methods, including:"Questionnaire aimed at the study of ideas about the object of activity (E. I. Rogova)," F. Zimbardo's time perspective Questionnaire (ZTPI)". Methods of mathematical and statistical processing, presentation of the obtained data: descriptive statistics, determination of the reliability of differences: according to the KruskalWallace criterion.

\section{Description of the study}

The study involved 148 College teachers. Work experience varies from 1 year to 40 years. Age limits from 20 to 63 years. The study was conducted in several stages. At the first stage, a theoretical analysis of the problem of professionalization in teaching was carried out. Further, according to the objectives of the study, the time perspective was studied by teachers of the technical school using The F. Zimbardo time perspective questionnaire (ZTPI). The sample of respondents was divided according to the age periodization of V. I. Slobodchikov and E. I. Isaeva: youth (19.0 years - 28.0 years); crisis of youth (27.0-33.0 years); adulthood 
- (32.0 years-42.0 years); crisis of adulthood (39.0 years-43.0 years); maturity (44.0 years 60.0 years). Thus, three groups of teachers participated in the empirical study: 1 group (youth) from 21 to 28 years; 2 group (adulthood) from 32 to 42 years; 3 group (Mature) from 44 to 60 years old. The results were processed statistically, the results were analyzed, and conclusions were made. Further, according to the objectives of the study, we studied the ideas about the object of activity of teachers of different ages using the Rogova E. I. method. the Results were processed statistically, the results were analyzed, and conclusions were made.

\section{Conclusion}

The following results were obtained using the method Of F. Zimbardo (ZTPI). It is established that for teachers of the group "youth" is characterized by the opinion that you need to live in the moment, today, now. They have certain goals and plans for the future, they accept their own past, in which any experience is an experience that contributes to development and led to the current state. Along with this, the teachers of the "youth" group have a certain rejection of their own past, which is disgusting, full of pain and frustration, the present is seen, to some extent, independent of the will of the individual, initially predetermined by fate. Teachers of the group "adulthood" are distinguished by the presence of plans for the future, but they see the present as detached from the past and future, the present is independent of the will of the individual, initially predetermined. Teachers of this group are distinguished by the rejection of their own past, which is disgusting, full of pain and frustration. To check the assumptions about the reliability of differences, we performed statistical data processing using the Kruskal-Wallace criterion. As a result, there were significantly significant differences in indicators for the perception factor "hedonistic present" $(\mathrm{H}=84,356, \mathrm{p}=0.000)$ and "positive past" $(\mathrm{H}=74,578, \mathrm{p}=0.000)$. Thus, it is proved that the indicators obtained in groups of teachers of different ages are statistically significantly different in a number of factors of time perception. Thus, focusing on average performance, we can say that the teachers of the group "youth" the present is perceived largely divorced from the past and the future, in contrast to the teachers of the group of "adulthood" and "maturity", now sees them, in a greater degree independent of the will of personality originally determined, but a person subordinate to destiny.

Further, according to the objectives of the study, we studied the ideas about the object of activity of teachers of different ages using the method of Rogov E. I., the degree of expression for all factors in teachers of different ages is different. Thus, the factor of rating the greatest degree of manifestation of teachers of group "maturity", lower the severity of the teachers of the group "youth" and the weak expression of teachers of group "maturity". Teachers of the "youth" group are distinguished by an insufficient level of acceptance of the object and a critical attitude towards it. Teachers of the maturity group tend to feel the low value of the object. According to the strength factor, the degree of severity is higher for teachers of the "adulthood" group, less pronounced for teachers of the "maturity" group, and the lowest severity for teachers of the "youth" group. Teachers of the group "adulthood" and "maturity" represent the object of activity to a greater extent passive and introverted. According to the factor definition the greatest severity was shown by the teachers of group "maturity", then, according to the degree of severity indicators of the group "maturity" and lower the severity on this factor have teachers group "youth". Consequently, the teachers of the group "adulthood" represent the image more accurate, contrasting, and adequate, in contrast to the teachers of other groups. To check the assumptions about the reliability of differences, we performed statistical data processing using the Kruskal-Wallace criterion. As a result, there were significantly significant differences in indicators for the evaluation factor $(\mathrm{H}=97.538$, $\mathrm{p}=0.000)$ and the activity factor $(\mathrm{H}=79.358, \mathrm{p}=0.000)$. 
Significant correlations were established. Thus, teachers of the "youth" group have a significant correlation between their ideas about the object of activity and such indicators of the time perspective as "positive past" and "fatalistic present". It is shown that with an increase in the degree of expression of indicators of the fatalistic present perception factor, the degree of expression of indicators for all factors of representations about the object of activity decreases: strength, activity, clarity and evaluation. For teachers of the "adulthood" group, the idea of the object of activity significantly correlates with such indicators of the time perspective as" fatalistic present "and"future". It is shown that with an increase in the degree of expression of indicators of the fatalistic present perception factor, the degree of expression of indicators for all factors of representations about the object of activity decreases: strength, activity, clarity and evaluation. The ideas about the object of activity of teachers of the "maturity" group significantly correlate with such indicators of the time perspective as" positive past "and" negative past". It is reliably established that with an increase in indicators for the factor of perception of the negative past, indicators for all factors of representations about the object of activity increase. Studied the ideas a bout the object of activity of teachers of different agesusing the Rogova E. I. method .the Results were processed statistically, there sults were analyzed, and conclusions were made.

\section{References}

1. D.G. Elkin, Perception of time (Moscow, 1962)

2. E.F. Zeer, Psychology of professional development (Publishing house "AcademiA", M., 2007)

3. A.G. Maslow, Motivation and personality (Peter, St. Petersburg, 2007)

4. E.Yu. Pryazhnikova, Labor Psychology: theory and practice: textbook (Yurayt publishing House, Moscow, 2012)

5. S.N. Chistyakova, School and production 1, 9-12 (2013)

6. O. Nikolenko, L. Zheldochenko and N. Lomova, E3s Web of Conferences 175, 15029 (2020) https://doi.org/10.1051/e3sconf/202017515029

7. L.D. Zheldochenko, E.I. Rogov, Proceedings of the southern Federal University. Pedagogical Sciences (SFU Publishing house, Rostov n/A, 2015)

8. A.M. Sheveleva, M.V. Naumenko, I.A. Pankratova, E.I. Rogov, L.D. Zheldochenko, Opción, Año 35, Especial 21, 1590-1607 (2019) ISSN 1012-1587/ISSNe: 2477-9385

9. E.I. Rogov, L.D. Zheldochenko, Advances in Social Science, Education and Humanities Research 321, 175-179 (2019)

10. A.V. Korochenceva, E.V. Carevich, Materialy nacional'noj nauchno-prakticheskoj konferencii «Aktual'nye problemy nauki i tekhniki», 1068-1069 (2019)

11. L. Zheldochenko, N.K. Epritskaya, SHS Web of Conferences 70, 08047 (2019) https://doi.org/10.1051/shsconf/20197008047

12. Ju. Rashupkina, O. Nikolenko, et al., INTED2017. 11th International Technology, Education and Development Conference Conference proceedings (IATED Academy, 2017)

13. A. Korochentseva, E. Suroedova, N. Khachaturyan and O. Nikolenko, SHS Web of Conferences 70, 08020 (2019) https://doi.org/10.1051/shsconf/20197008020

14. F. Zimbardo, J. Boyd, The Paradox of time (Speech, SPb, 2010)

15. A. Syrtsova, O.V. Mitina, Question of psychology 2, 41-54 (2008) 
16. A.B. Hernández-Lara, E. Serradell-López, Behaviour and Information, Technology 37(4.3), 419-429 (2018) doi: 10.1080/0144929X.2018.1441326 